\title{
Colletotrichum acutatum Overwinters on Sweet Cherry Buds
}

Jorunn Børve, Norwegian Institute for Agricultural and Environmental Research, Ullensvang, N-5781 Lofthus, Norway; and Arne Stensvand, Norwegian Institute for Agricultural and Environmental Research, Høgskoleveien 7, N-1432 Ås, Norway

\begin{abstract}
Børve, J., and Stensvand, A. 2006. Colletotrichum acutatum overwinters on sweet cherry buds. Plant Dis. 90:1452-1456.

Either naturally infected or artificially inoculated sweet cherry (Prunus avium) buds on fruit spurs (mainly containing generative buds) and on 1-year-old shoots (mainly containing vegetative buds) were examined for presence of Colletotrichum acutatum prior to the beginning of spring growth in each of 4 years. Artificial inoculations were made during the growing seasons preceding the bud sampling. The plant material was incubated moist for either 14 (fruit spurs) or 21 (1-year-old shoots) days at $20^{\circ} \mathrm{C}$. Following moist incubation at $20^{\circ} \mathrm{C}, \mathrm{C}$. acutatum frequently sporulated on buds of fruit spurs and shoots. The fungus sporulated in orange, short-thread or hornlike structures, mainly on distal parts of the buds, and was usually easily visible with the unaided eye. The incidence of infected buds on naturally infected and inoculated fruit spurs was 2 to $80 \%$ and 38 to $79 \%$, respectively. Incidence on naturally infected and inoculated shoots was 0 to $53 \%$ and 4 to $45 \%$, respectively. On buds within fruit spurs, the incidence of C. acutatum was significantly higher on generative than on vegetative buds. This investigation shows that buds can host $C$. acutatum and thus are likely to be an important source of primary inoculum for anthracnose of sweet cherry.
\end{abstract}

Additional keywords: bitter rot

In Norway, anthracnose, also called bitter rot, in sweet cherry (Prunus avium L.) was believed to be caused by Colletotrichum gloeosporioides (Penz.) Penz. \& Sacc. $(4,5)$, but all recently collected isolates from sweet cherry in Norway have been classified by polymerase chain reaction analysis as Colletotrichum acutatum Simmonds ex. Simmonds (15).

Anthracnose may be a major cause of fruit decay in sweet cherry in Norway $(4,5,6)$. In sweet cherry in Switzerland (3) and sour cherry in Norway (A. Stensvand, unpublished data), it was found that fruit peduncles and mummified fruits might be sources of inoculum for Colletotrichum spp. In almond, overwintering fruit mummies may be an important inoculum source for C. acutatum in California $(1,9)$ and in Israel (14). Other possible inoculum sources in almond may be peduncles, fruit spurs, and wood with dieback symptoms (9). In well-managed sweet cherry orchards, mummified fruits and peduncles left from the previous year are usually rare, because nearly all fruits and peduncles are picked by hand during harvest or removed prior to the next growing season during

Corresponding author: J. Børve

E-mail: jorunn.borve@bioforsk.no

Accepted for publication 13 June 2006.

DOI: 10.1094/PD-90-1452

(C) 2006 The American Phytopathological Society pruning. C. acutatum is found to overwinter on buds of highbush blueberry in New Jersey (8), mulberry in Japan (16), and sour cherry in Norway (A. Stensvand, unpublished data), and both C. acutatum and $C$. gloeosporioides have been detected on apple buds in Brazil $(2,7)$. The objective of the present investigation was to determine whether $C$. acutatum could survive over winter on sweet cherry buds and thus be a potential source of inoculum in spring.

\section{MATERIALS AND METHODS}

Sweet cherry buds were assessed prior to bud break for infections of C. acutatum on trees that were either naturally infected or artificially inoculated the previous year. The experiments took place in Ullensvang in southwestern Norway.

Natural infections. Two commercial orchards (Sekse and Opedal) and three research plantings at Ullensvang (Fagravoll, Kvitavoll, and Storåkeren) were included in a survey of bud infections from 2002 to 2005 (Table 1). The Sekse orchard had previously had serious epidemics of anthracnose. The cultivars included in the present survey-Kristin, Van, and Vistawere planted in 1993. The orchard was treated using commercial practices; free spindle-shaped trees, vegetation-free strips in the tree rows, and regular fungicide applications against brown rot and gray mold. In the Opedal orchard, visible symptoms of anthracnose had been found previously on Kristin to a limited extent, but not on Van or Ulster, the three cultivars included in this survey. The trees were planted in 1985 and treated as in the Sekse orchard. The three research plantings were separated from each other by 200 to 1,200 $\mathrm{m}$. Kvitavoll was part of a cultivar collection planted in 1994 (cvs. Kristin and Sue included in this survey), and Fagravoll was a cultivar trial planted the same year (cvs. Lapins, Sunburst, and Van included in this survey). Both research plantings were treated the same as those in the commercial orchards. Storåkeren was planted for pesticide experiments in 1999 (cvs. Burlat, Lapins, and Van included in this survey). Anthracnose had been observed previously on fruits of Kristin at Kvitavoll and Van at Fagravoll.

Cherry buds can be either generative (fruiting) or vegetative, and the anatomical terminology for these is complicated by the fact that fruit spurs are a structural feature composed of both types. Typically, 1-year-old wood, also termed shoots, produces vegetative buds on the middle to distal portions and generative buds (normally three to five) at the base. Two-yearold wood produces fruit spurs, each containing two to nine generative buds, most commonly four or five, and one or two vegetative buds. Vegetative buds are normally located in the center of the tip of each fruit spur and are surrounded by generative buds (Fig. 1). Both generative and vegetative buds were sampled prior to bud break. In each orchard, 10 fruit spurs and one shoot were sampled from three different groups of trees for a total of 30 fruit spurs and three shoots from each location and cultivar. Ten pieces (each 2 to $5 \mathrm{~cm}$ in length and containing one bud) were cut from each shoot (Fig. 1). Thus, $3 \times 10$ shoot pieces with one vegetative bud each and $3 \times 10$ fruit spurs were incubated from each orchard and cultivar each time. Shoot pieces and fruit spurs were placed separately on metal grids in sealed plastic boxes and incubated for 14 (fruit spurs) or 21 (shoot parts) days at $20^{\circ} \mathrm{C}$. A wet paper towel was placed at the bottom of each box in order to maintain the air saturated. After incubation, buds on each plant part were examined for visible signs of sporulation of $C$. acutatum by use of a stereo magnifier (Wild M3B, Leica). The presence of the fungus was confirmed by microscopy. On each fruit spur, the number of infected vegetative or generative buds was recorded (infections were not distinguished by bud types in 2002). 
Artificial inoculation. Artificial inoculations were carried out on established trees at Sekse, cv. Van, and in a field named Osa at Ullensvang Research Centre with trees of cvs. Van and Lapins planted in 2002 (Table 2). The trees at Osa did not receive any fungicide treatment during the years of experiments.

Each branch was inoculated with suspensions of $1 \times 10^{5}$ conidia $/ \mathrm{ml}$ of $C$. acutatum. The suspension was sprayed to runoff with a handheld sprayer. The same isolate was used throughout the experiments. After inoculation, each of the branches was enclosed by a milky-white plastic bag for $48 \mathrm{~h}$. The timing of inoculation and incubation differed with site and year. At Osa, branches containing approximately 10 buds each were inoculated at the following phenological stages in 2002, bud swell, full bloom, and early green fruit, and in 2003 at petal fall and at early green fruit. One branch was inoculated on each of 10 trees each time. Prior to bud break the following year, 1-year-old growth was cut into pieces containing one vegetative bud each, and fruit spurs were cut from the 2-year-old wood and incu- bated and assessed as described above. In 2003, all the pieces cut from the branches were incubated. The following year, 10 shoot parts with one bud each and all the fruit spurs from each branch were incubated.

At Sekse, branches of cv. Van containing 10 fruit spurs each were inoculated early in fruit development in 2003; six branches at full bloom, five at petal fall, and four at early green fruit. Fruits were removed from the inoculated branches at five different times: at petal fall, at early green fruit, at green fruit, at yellow fruit, and at harvest. The following spring all the inoculated branches were incubated during time of bud swell (28 March). Ten fruit spurs and 10 shoot parts (not all the branches had new growth) from each of the inoculated branches were incubated and assessed as described above.

Weather data and statistical analysis. Weather data were obtained from a weather station located at Ullensvang Research Centre, up to $1,200 \mathrm{~m}$ from the individual research fields, $800 \mathrm{~m}$ from the Opedal orchard, and $10 \mathrm{~km}$ from the Sekse orchard. Data were analyzed statistically by the GLM procedure of SAS (SAS Institute, Cary, NC), and differences between means were separated by StudentNewman-Keul's method at $\alpha=0.05$. When comparing incidence of $C$. acutatum between generative and vegetative buds, the incidences were weighted according to number of buds in each category by the procedure WEIGHT. Data from each experiment and year were analyzed separately.

\section{RESULTS}

The experiments were conducted for 4 years, and the monthly mean temperatures during winter (November to March) were above the historical average every month except November 2002 (Table 3). The lowest temperatures observed were $-9.9^{\circ} \mathrm{C}$ (December 2001) and $-9.2^{\circ} \mathrm{C}$ (March 2005). In every month during the four winters that the experiments were conducted, temperatures below $0^{\circ} \mathrm{C}$ were observed.

The fungus was usually found sporulating along the edges of bud scales on the upper parts of the buds. We did not separate the bud scales to investigate exactly which scales showed initial sporulation.

Table 1. Incidence (\%) of buds on fruit spurs and 1-year-old wood (shoots) of sweet cherry naturally infected with Colletotrichum acutatum $^{\text {a }}$

\begin{tabular}{|c|c|c|c|c|c|c|c|}
\hline \multirow[b]{2}{*}{ Orchard $^{\text {b }}$} & \multirow[b]{2}{*}{ Cultivar } & \multirow[b]{2}{*}{ Year } & \multicolumn{2}{|c|}{ Fruit spurs } & \multicolumn{2}{|c|}{ Shoots } & \multirow[b]{2}{*}{$P$ value $^{\mathrm{e}}$} \\
\hline & & & $\begin{array}{c}\text { C. acutatum } \\
(\%)^{\mathrm{c}}\end{array}$ & $\begin{array}{l}\text { No. of buds } \\
\text { examined }^{\text {d }}\end{array}$ & $\begin{array}{c}\text { C. acutatum } \\
(\%)^{\mathrm{c}}\end{array}$ & $\begin{array}{l}\text { No. of buds } \\
\text { examined }^{\text {d }}\end{array}$ & \\
\hline \multirow[t]{3}{*}{ Fagravoll } & Lapins & 2003 & 27.8 & 562 & 44.4 & 90 & 0.29 \\
\hline & Sunburst & 2003 & 10.2 & 152 & 53.3 & 30 & 0.01 \\
\hline & Van & 2003 & 45.7 & 612 & 26.7 & 90 & 0.19 \\
\hline \multirow{3}{*}{ Kvitavoll } & Kristin & 2002 & 41.5 & 53 & $-\mathrm{f}$ & - & - \\
\hline & & 2003 & 25.4 & 417 & 34.4 & 90 & 0.24 \\
\hline & Sue & 2002 & 27.3 & 88 & - & - & - \\
\hline \multirow[t]{3}{*}{ Opedal } & Kristin & 2003 & 34.4 & 453 & 4.4 & 90 & 0.0001 \\
\hline & Ulster & 2003 & 3.9 & 427 & 2.2 & 90 & 0.6 \\
\hline & Van & 2003 & 32.5 & 621 & 16.7 & 90 & 0.2 \\
\hline \multirow[t]{12}{*}{ Sekse } & Kristin & 2002 & 79.5 & 44 & 9.7 & 255 & - \\
\hline & & 2003 & 35.6 & 452 & 14.6 & 84 & 0.03 \\
\hline & & 2004 & 45.9 & 462 & 15.6 & 90 & 0.007 \\
\hline & & 2005 & 26.0 & 307 & 3.8 & 60 & 0.18 \\
\hline & Van & 2002 & - & - & 0 & 110 & - \\
\hline & & 2003 & 16.0 & 609 & 10 & 90 & 0.41 \\
\hline & & 2004 & 45.5 & 589 & 5.5 & 90 & 0.002 \\
\hline & & 2005 & 31.2 & 394 & 0.3 & 60 & 0.03 \\
\hline & Vista & 2002 & - & - & 1.6 & 62 & - \\
\hline & & 2003 & 12.2 & 507 & 1.1 & 90 & 0.007 \\
\hline & & 2004 & 47.0 & 539 & 22.2 & 90 & 0.09 \\
\hline & & 2005 & 15.5 & 332 & 15.0 & 60 & 0.99 \\
\hline \multirow[t]{6}{*}{ Storåkeren } & Burlat & 2003 & 1.8 & 118 & 0 & 30 & 0.4 \\
\hline & Lapins & 2003 & 25.3 & 340 & 3.3 & 60 & 0.004 \\
\hline & & 2004 & 11.6 & 184 & 20 & 30 & 0.6 \\
\hline & Van & 2002 & - & - & 1.7 & 60 & - \\
\hline & & 2003 & 19.1 & 365 & 0 & 60 & 0.03 \\
\hline & & 2004 & 13.3 & 170 & 6.7 & 30 & 0.24 \\
\hline
\end{tabular}

${ }^{\text {a }}$ Fruit spurs and shoots (containing mainly generative and vegetative buds, respectively) were collected prior to bud break and incubated at $20^{\circ} \mathrm{C}$ for 14 (fruit spurs) or 21 (shoots) days.

b Sekse and Opedal were commercial orchards, whereas Kvitavoll, Fagravoll, and Storåkeren were research fields at Ullensvang Research Centre.

${ }^{\mathrm{c}}$ Mean of one to six incubation times from February to bud break (April).

${ }^{\mathrm{d}}$ Total number of buds from all replicates.

${ }^{\text {e }} P$ values indicate whether the difference in infections on buds from fruit spurs and from shoots were significant or not. Incidences were weighted according to number of buds in each mean in the analysis.

f $-=$ No records. 
The fungus sporulated in orange, short thread- or horn-like masses, usually easily visible by the unaided eye (Fig. 1). C. acutatum was observed on buds from fruit spurs of all cultivars and in all orchards and years included in this survey (on 2 to $80 \%$ of the buds) (Table 1). On buds on shoots, the fungus appeared on all but one cultivar in 2002 and all but two cultivars in 2003 (on 0 to $53 \%$ of the vegetative buds). C. acutatum was also found to sporulate on the cut ends of the shoot parts. From 0 to $12 \%$ of the shoot ends had visible sporulation (data not shown). A few times the fungus was observed to sporulate through the bark along the shoot pieces, both towards the cut ends and elsewhere on the shoot pieces, but this was not quantified. Sporulation through the bark of fruit spurs was found on 2 of the 1,852 fruit spurs assessed for natural infections.

In 17 of 21 sites/cultivars in 2003 to 2005, a higher incidence of $C$. acutatum was found on buds on fruit spurs than on buds on shoot pieces, and the difference was significant in 8 of them. In one case, there was a significantly higher incidence on buds located on shoots (Table 1).

On fruit spurs, the number of generative buds was always higher than on vegetative

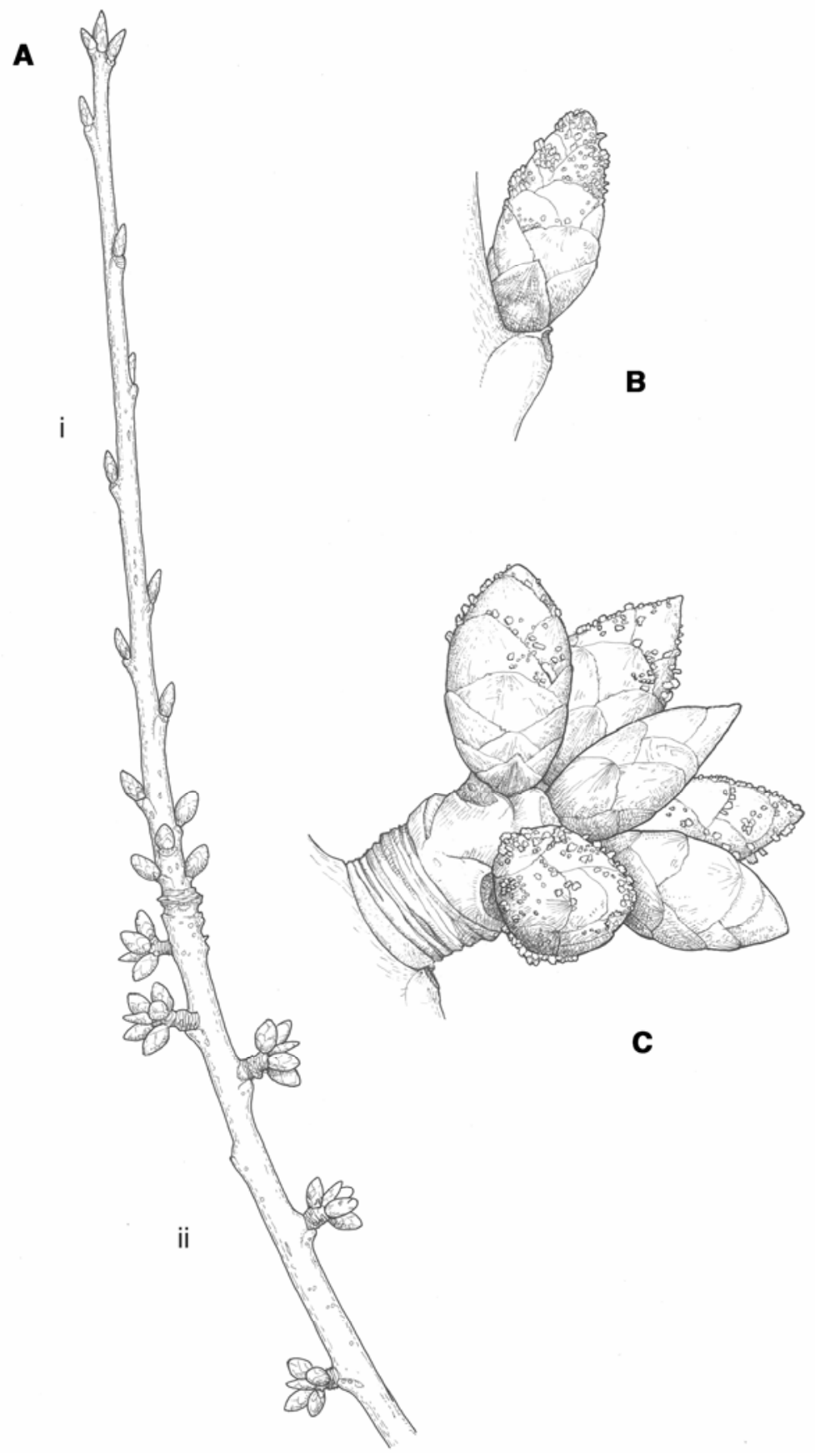

Fig. 1. A, Branch of sweet cherry with 1-year-old wood with vegetative buds on the upper part (i) and generative buds on the lower part and 2-year-old wood with fruit spurs (ii); B, a vegetative bud with sporulation of Colletotrichum acutatum on 1-year-old wood; and $\mathbf{C}$, fruit spur with sporulation of $C$. acutatum. buds for all cultivars assessed. When comparing the incidence of naturally infected buds of the two categories at the Sekse orchard, the incidence was significantly higher on generative than on vegetative buds on all three cultivars and in all years (2003 to 2005) (Table 4).

Infections occurring after artificial inoculation. The pathogen appeared on buds from fruit spurs or shoots the following spring on all cultivars for both years (Table 2). On the young trees at Osa, more C. acutatum developed on buds on fruit spurs than on buds on shoots of both cultivars in both years (Table 2). The incidence of $C$. acutatum was significantly higher on buds from branches inoculated at early green fruit compared with buds on branches inoculated at bud swell or at full bloom of Van in $2002(P=0.02)$. There were no significant differences between different times of inoculation on Lapins for both years or on Van in 2003 (data not shown).

\section{DISCUSSION}

C. acutatum survives over winter in naturally infected sweet cherry buds in Norway, often at high frequency. Bud infections may therefore be an important source of inoculum for emerging flowers and leaves in spring. The pathogen survived the winter conditions in Ullensvang from 2001 to 2005. C. acutatum is also commonly found on sour cherry buds in southeastern Norway (A. Stensvand, unpublished data), where winters may be more severe than in Ullensvang (monthly mean temperatures are typically 3 to $5^{\circ} \mathrm{C}$ below temperatures at Ullensvang). Thus, winter temperatures do not seem to limit the ability of the fungus to survive on cherry buds in Norway.

The incidence of $C$. acutatum infections was higher on buds located on fruit spurs than on shoots in 17 of 21 sites/cultivars assessed, however, the differences were significant only in 8 . It may be more difficult for the pathogen to grow and sporulate on vegetative buds on shoots than on generative buds, as indicated by the fact that vegetative buds had to be incubated longer than buds on fruit spurs before visible sporulation appeared. Also, when the vegetative buds were located next to generative buds on fruit spurs, the latter had a higher incidence of infected buds. Growth on vegetative buds must be slower, since vegetative and generative buds on fruit spurs were incubated for the same amount of time. If the vegetative buds on fruit spurs had been incubated longer, there is a possibility that sporulation would have appeared on more of these buds. Under field conditions in Norway, visible symptoms and sporulation of $C$. acutatum have been observed only on nonabscised, aborted fruits or on ripe fruits, both attached to fruit spurs. Nonabscised, aborted fruits infected with $C$. acutatum may be 
present in the orchard until 8 weeks after anthesis (5). Fruit spurs produce flower buds for several years, and both aborted and ripening fruits infected with $\mathrm{C}$. $a c u$ tatum attached to the spurs may produce high numbers of conidia within a short distance of newly formed buds. Conidia of $C$. acutatum are dispersed only in water droplets, and the longer distance from infected fruits to vegetative buds on newly emerged shoots may lead to fewer infections. Our results agree with those from highbush blueberry buds, where a higher incidence of $C$. acutatum was found on generative than on vegetative buds (8).

Survival of $C$. acutatum during the intercrop period on sweet cherry is poorly understood for C. acutatum. However, an earlier investigation with $C$. gloeosporioides on sweet cherry in Switzerland showed that infections of shoots could take place during autumn and winter, and the fungus was found to grow in conductive tissue (3). Such twig infections supposedly reduced the number of flowers and in- creased fruit abortion in the next growing season (17). In the present study, C. acutatum was present in the trees without causing visible damage to the trees, and it was detected year after year in trees with yields and growth that was normal for the area.

In Switzerland, C. gloeosporioides was found as acervuli on bud scales the year after inoculation of branches (3). We did not observe acervuli on the outer parts of the bud scales before incubation. Usually, the pathogen sporulated more intensely toward the tip of the buds than toward the base (Fig. 1). All outer bud scales are lignified (dark brown) before bud swell. However, bud scales toward the tip of the buds are covered by other scales towards the base, and are themselves green at the base. Thus, the fungus may have survived the winter on green tissue protected by lignified scales, and when incubated under optimum conditions, it sporulated abundantly along the upper edge of the scales. In experiments with blueberry buds, bud scales were separated, and the outermost ones were found to be more frequently infected than the inner ones (8). In blueberry, appressoria are proposed as the overwintering form of the pathogen (8), and on almond overwintering takes place as conidia or mycelium $(1,9)$. On mulberry in Japan (16) or on apple buds in Brazil $(2,7)$, the overwintering form was not specified. However, C. acutatum is known to survive periods without susceptible host tissue as appressoria in citrus (18) and as conidia and appressoria in strawberry $(10,11,12)$.

The importance of buds as a source of initial inoculum in epidemics of anthracnose on sweet cherry remains unresolved. Important sources of inoculum in mechanically harvested stone fruits, peduncles and mummified fruits (1), are rare in handpicked sweet cherry. C. acutatum can infect many host plants (13). In Norway the fungus is found on all pome and stone fruits grown commercially (15). However, since $C$. acutatum is dispersed by water splash, inoculum coming from the host plant itself is more likely to be important

Table 2. Incidence (\%) of buds infected with Colletotrichum acutatum on fruit spurs and 1-year-old wood (shoots) of sweet cherry that were artificially inoculated at different times during the growing season preceding the year of examination

\begin{tabular}{|c|c|c|c|c|c|c|c|c|}
\hline \multirow[b]{2}{*}{ Orchard $^{b}$} & \multirow[b]{2}{*}{ Cultivar } & \multirow[b]{2}{*}{ Year } & \multirow[b]{2}{*}{ Time of inoculation } & \multicolumn{5}{|c|}{ Percentage of buds with $C$. acutatum and number of buds examined } \\
\hline & & & & Fruit spurs (\%) & No. of buds & Shoots $(\%)$ & No. of buds & $P$ value \\
\hline Sekse & Van & 2003 & Full bloom, petal fall or early green fruit & 60.4 & 750 & 25.7 & 47 & - \\
\hline Osa & Lapins & 2002 & Bud swell, full bloom or early green fruit & 37.7 & 246 & 5.8 & 178 & 0.04 \\
\hline Osa & Lapins & 2003 & Petal fall or early green fruit & 67.0 & 122 & 5.0 & 40 & 0.004 \\
\hline Osa & Van & 2002 & Bud swell, full bloom or early green fruit & 40.9 & 299 & 3.9 & 171 & 0.002 \\
\hline Osa & Van & 2003 & Petal fall or early green fruit & 79.0 & 119 & 45.0 & 40 & 0.008 \\
\hline
\end{tabular}

${ }^{a}$ Fruit spurs and shoot parts (containing mainly generative and vegetative buds, respectively) were collected prior to bud break and incubated at $20^{\circ} \mathrm{C}$ for 14 (fruit spurs) or 21 (shoots) days.

b Sekse was a commercial orchard whereas Osa was an experimental field.

${ }^{\mathrm{c}} P$ values indicate whether the difference in infections on buds from fruit spurs and shoots were significant or not. The incidences were weighted according to number of buds behind each mean in the analysis. The incidences on fruit spurs and shoots were not compared on cv. Van, Sekse, 2003, because of the low number of vegetative buds.

Table 3. Monthly mean and minimum temperatures $\left({ }^{\circ} \mathrm{C}\right)$ during winter (November-March) recorded at Ullensvang Research Centre, 2001-2005

\begin{tabular}{|c|c|c|c|c|c|c|c|c|c|c|}
\hline \multirow[b]{2}{*}{ Year } & \multicolumn{2}{|c|}{ November } & \multicolumn{2}{|c|}{ December } & \multicolumn{2}{|c|}{ January } & \multicolumn{2}{|c|}{ February } & \multicolumn{2}{|c|}{ March } \\
\hline & Mean & Min & Mean & Min & Mean & Min & Mean & Min & Mean & Min \\
\hline $2001-2002$ & 4.2 & -2.6 & 0.1 & -9.9 & 1.7 & -3.8 & 2.3 & -7.8 & 2.6 & -5.5 \\
\hline $2002-2003$ & 2.2 & -4.2 & 0.5 & -6.5 & 1.4 & -8.6 & 0.2 & -8.0 & 3.5 & -3.3 \\
\hline 2003-2004 & 6.0 & -0.3 & 3.2 & -6.1 & 0.3 & -8.9 & 1.2 & -8.0 & 4.7 & -2.7 \\
\hline 2004-2005 & 3.2 & -4.5 & 3.8 & -5.1 & 3.0 & -5.7 & 1.0 & -6.6 & 2.3 & -9.2 \\
\hline Historical average ${ }^{a}$ & 3.1 & - & 0.9 & - & -0.2 & - & -0.4 & - & 1.7 & - \\
\hline
\end{tabular}

${ }^{a}$ Monthly means for the period 1961 to 1990 .

Table 4. Incidence (\%) of Colletotrichum acutatum on generative and vegetative buds on fruit spurs from three cultivars in a commercial orchard (Sekse)

\begin{tabular}{|c|c|c|c|c|c|c|c|}
\hline \multirow[b]{2}{*}{ Cultivar } & \multirow[b]{2}{*}{ Buds } & \multicolumn{2}{|c|}{2003} & \multicolumn{2}{|c|}{2004} & \multicolumn{2}{|c|}{2005} \\
\hline & & Buds per spur & Anthracnose $(\%)^{\mathrm{a}}$ & Buds per spur & $\overline{\text { Anthracnose }(\%)^{\mathrm{a}}}$ & Buds per spur & Anthracnose (\%) \\
\hline Kristin & $\begin{array}{l}\text { Generative } \\
\text { Vegetative } \\
P \text { value }\end{array}$ & $\begin{array}{c}3.6 \\
1.0 \\
0.0001\end{array}$ & $\begin{array}{c}43.6 \\
17.8 \\
0.0004\end{array}$ & $\begin{array}{c}4.1 \\
1.1 \\
0.0001\end{array}$ & $\begin{array}{l}51.3 \\
32.5 \\
0.03\end{array}$ & $\begin{array}{c}3.3 \\
1.1 \\
0.0001\end{array}$ & $\begin{array}{c}35.7 \\
3.5 \\
0.0001\end{array}$ \\
\hline Vista & $\begin{array}{l}\text { Generative } \\
\text { Vegetative } \\
P \text { value }\end{array}$ & $\begin{array}{c}3.9 \\
1.0 \\
0.0001\end{array}$ & $\begin{array}{c}17.4 \\
6.7 \\
0.03\end{array}$ & $\begin{array}{c}4.6 \\
1.1 \\
0.0001\end{array}$ & $\begin{array}{c}55.7 \\
20.7 \\
0.0001\end{array}$ & $\begin{array}{c}4.0 \\
1.0 \\
0.0001\end{array}$ & $\begin{array}{c}20.4 \\
0 \\
0.0001\end{array}$ \\
\hline Van & $\begin{array}{l}\text { Generative } \\
\text { Vegetative } \\
P \text { value }\end{array}$ & $\begin{array}{c}5.5 \\
1.0 \\
0.0001\end{array}$ & $\begin{array}{c}18.0 \\
0 \\
0.0001\end{array}$ & $\begin{array}{c}4.9 \\
1.1 \\
0.0001\end{array}$ & $\begin{array}{c}43.0 \\
19.3 \\
0.0006\end{array}$ & $\begin{array}{c}5.2 \\
1.1 \\
0.0001\end{array}$ & $\begin{array}{c}36.9 \\
4.2 \\
0.0001\end{array}$ \\
\hline
\end{tabular}

\footnotetext{
a Means of two (2005) or three (2003 and 2004) sampling times at bud swell $(3 \times 10$ fruit spurs each time).
} 
than inoculum from other hosts nearby. Thus, overwintering bud infections on the sweet cherry host itself may be a very important source of inoculum in commercial sweet cherry orchards.

Spraying twice with dithianon during the green fruit stage greatly reduced anthracnose on fruits at harvest in experiments in Norway (6). However, we do not know when buds are infected and thus at what time fungicides should be applied to prevent such infections, nor do we know which fungicides may be the most efficient in reducing the number of bud infections. Covering sweet cherry trees with plastic shields the last 3 to 4 weeks prior to harvest is a common practice to avoid fruit cracking, and this greatly reduces fruit decay caused by fungal pathogens (4). Whether this practice also has an effect on bud infections is not known. Future research should address these questions to further improve management of anthracnose in sweet cherry.

\section{ACKNOWLEDGMENTS}

The Ministry of Agriculture and The Norwegian Industrial and Regional Development Fund supported the experiments financially. The authors thank the growers E. Børve and S. Opedal for providing trees and buds for the experiments. We also thank the technicians at Ullensvang Research Centre for their help.

\section{LITERATURE CITED}

1. Adaskaveg, J. E., and Förster, H. 2000. Occurrence and management of anthracnose epidemics caused by Colletotrichum species on tree fruit crops in California. Pages 317-336 in Colletotrichum. Host Specificity, Pathology, and Host-Pathogen Interaction. D. Prusky, S. Freeman, and M. B. Dickman, eds. APS Press, St. Paul, MN

2. Bernardi, J., Feliciano, A., and De Assis, M. 1983. Ocorrẽncia de Glomerella cingulata (Colletotrichum gloeosporioides) nas gemas florais e flores de macieira (Occurrence of Glomerella cingulata [Colletotrichum gloeosporioides] in dormant floral buds and flowers of apple.) Pesqui. Agropecu. Bras. 18:609-611.

3. Böhni, E. 1949. Untersuchungen über die Bitterfäule an Kirschen. Phytopathol. Z. 15:333-375.

4. Børve, J., and Stensvand, A. 2003. Use of a plastic rain shield reduces fruit decay and need for fungicides in sweet cherry. Plant Dis. 87:523-528.

5. Børve, J., and Stensvand, A. 2004. Nonabscised aborted sweet cherry fruits are vulnerable to fruit decaying fungi and may be sources of infection for healthy fruits. Acta Agric. Scand. 54:31-37

6. Børve J., and Stensvand, A. 2006. Timing of fungicide applications against anthracnose in sweet and sour cherry production in Norway. Crop Prot. 25:781-787.

7. Crusius, L. U., Forcelini, C. A., Sanhueza, R. M. V., and Fernandes, J. M. C. 2002. Epidemiology of apple leaf spot. Fitopatol. Bras. 27:65-70.

8. De Marsay, A. 2005. Anthracnose fruit rot of highbush blueberry: Biology and epidemiology. Ph.D. diss. Rutgers, The State University of New Jersey.

9. Förster, H., and Adaskaveg, J. E. 1999. Identification of subpopulations of Colletotrichum acutatum and epidemiology of almond anthracnose in California. Phytopathology 89:1056-1065.

10. Leandro, L. F. S., Gleason, M. L., Nutter, F. W., Wegulo, S. N., and Dixon, P. M. 2001.
Germination and sporulation of Colletotrichum acutatum on symptomless strawberry leaves. Phytopathology 91:659-664.

11. Leandro, L. F. S., Gleason, M. L., Nutter, F. W., Wegulo, S. N., and Dixon, P. M. 2003. Influence of temperature and wetness duration on conidia and appressoria of Colletotrichum acutatum on symptomless strawberry leaves. Phytopathology 93:513-520.

12. Leandro, L. F. S., Gleason, M. L., Nutter, F. W., Wegulo, S. N., and Dixon, P. M. 2003. Strawberry plant extracts stimulate secondary conidiation by Colletotrichum acutatum on symptomless leaves. Phytopathology 93:12851291.

13. Peres, N. A., Timmer, L. W., Adaskaveg, J. E., and Correll, J. C. 2005. Lifestyles of Colletotrichum acutatum. Plant Dis. 89:784-796.

14. Shabi, E., and Katan, T. 1983. Occurrence and control of anthracnose of almond in Israel. Plant Dis. 67:1364-1366.

15. Stensvand, A., Talg $\varnothing$, V., Strømeng, G. M., Børve, J., Sletten, A., and Klemsdal, S. S. 2006. Colletotrichum acutatum in Norwegian strawberry production and sources of potential inoculum in and around strawberry fields. 5th Int. Org. Biol. Control meeting of Working Group "Integrated Plant Protection in Fruit Crops" (Sub Group "Soft Fruits"). IOBC/wprs Bull. In press.

16. Yoshida, S., and Shirata, A. 1999. The mulberry anthracnose fungus, Colletotrichum acutatum, overwinters on a mulberry tree. Ann. Phytopathol. Soc. Jpn. 65:274-280.

17. Zobrist, L., Conrad, R., and Zogg, H. 1944 Untersuchungen über die GloeosporiumFruchtfäule an Kirschen. Schweiz. Z. ObstWeinbau 53:145-169.

18. Zulfiqar, M., Brlansky, R. H., and Timmer, L. W. 1996. Infection of flower and vegetative tissue of citrus by Colletotrichum acutatum and C. gloeosporioides. Mycologia 88:121128. 